Claremont Colleges

Scholarship@ Claremont

Scripps Faculty Publications and Research

Scripps Faculty Scholarship

$1-1-1991$

\title{
Feminist Fiction and the Uses of Memory
}

Gayle Greene

Scripps College

\section{Recommended Citation}

Greene, Gayle. "Feminist Fiction and the Uses of Memory," Signs, Winter, 1991, 16, 2, 290-321.

This Article is brought to you for free and open access by the Scripps Faculty Scholarship at Scholarship @ Claremont. It has been accepted for inclusion in Scripps Faculty Publications and Research by an authorized administrator of Scholarship @ Claremont. For more information, please contact scholarship@cuc.claremont.edu. 


\section{FEMINIST FICTION AND THE USES OF MEMORY}

\section{GAYLE GREENE}

The gap between the known potential-who you once were and wanted to be-and what your housewife role has turned you into, is enormous and, in most cases, unbridgable. The hordes of happy housewives that every man testifies to when the role of women is being discussed are simply those women who have successfully forgotten who they might have been. The act of forgetting is their only contribution to the world. [Lee Sanders Comer, Women's Liberation Review, $1972]^{1}$

He has stolen your wisdom from you, he has closed your memory to what you were, he has made of you that which is not which does not speak which does not possess which does not write. . . . He has invented your history. . . But remember. Make an effort to remember. Or, failing that, invent. [Monique Wittig, Les guerilleres, 1969] ${ }^{2}$

With thanks to the Scripps Humanities Institute and especially to Michael S. Roth, Elizabeth Minnich, and Jean Wyatt. The section on Beloved was enriched by conve rsations with Toni Morrison, Sue Houchins, Toni Clark, and Cris Miller. Parts of this article were read at Scripps College and at "The Poetics and Politics of Women's Writing," Dubrovnik, Yugoslavia, May 1988.

${ }^{1}$ Lee Sanders Comer, Women's Liberation Review (1972), as quoted in Rewriting English: Cultural Politics of Gender and Class, ed. Janet Batsleer, Tony Davies, Rebecca O'Rourke, and Chris Weedon (New York: Methuen, 1985), 139.

${ }^{2}$ Monique Wittig, Les guerilleres (Boston: Beacon, 1985), 110-11, 89. 
All writers are concerned with memory, since all writing is a remembrance of things past; all writers draw on the past, mine it as a quarry. Memory is especially important to anyone who cares about change, for forgetting dooms us to repetition; and it is of particular importance to feminists. This essay concerns feminist fiction by Doris Lessing, Margaret Drabble, Margaret Atwood, Margaret Laurence, and Toni Morrison that addresses memory as a means to liberation and explores this at the level of narrative form. ${ }^{3}$

Feminist fiction is not the same as "women's fiction" or fiction by women. Not all women writers are women's writers and not all women's writers are feminist writers, since to write avout "women's issues" is not necessarily to address them frolii a feminist perspective. Nor are feminist writers necessarily so all the timeLessing is feminist in The Golden Notebook (1962) an i is not in The Diaries of Jane Somers (1984); nor do they necessarily identify themselves as feminists. Yet whatever a writer's relation to the women's movement, a novel may be termed "feminist" for its analysis of gender as socially constructed and capable of being reconstructed and for its enlistment of narrative in the process of change.

In a sense, all narrative is concerned with change: there is something in the impulse to narrative that is related to the impulse to liberation. Narrative re-collects, re-members, repeats-as Peter Brooks and others have said-in order for there to be an escape from repetition, in order for there to be change or progress; like psychotherapy, it aspires to "a narrative redescription of reality," to a "new

${ }^{3}$ All of Doris Lessing's major works are concerned with change: Martha Quest, overwhelmed by her sense of "the nightmare repetition," wearied that "It had all been done and said already" (A Proper Marriage, 77, 95, 34 [hereafter cited as PM]), determines "to move onto something new" (Martha Quest, 8-9 [hereafter cited as MQ]). The term "something new" recurs in The Golden Notebook (New York: Bantam, 1973), 61, 353, 472-73, 479 (hereafter cited as GN), in Martha Quest, 53, 141, 216, Landlocked, 117, and The Four-Gated City, 69, 176 (hereafter cited as FGC). (References to Children of Violence are to the New American Library editions; A Ripple from the Storm is referred to as RS.) Margaret Drabble describes women's writing as providing "patterns . . . for a possible future," "actively engaged in creating a new pattern, a new blueprint" ("A Woman Writer," in On Gender and Writing, ed. Michelene Wandor [London: Pandora, 1983], 156-59, esp. 159). Margaret Laurence also describes her work as "an attempt at something new" ("Gadgetry or Growing: Form and Voice in the Novel," Journal of Canadian Fiction ["The Work of Margaret Laurence," ed. John R. Sorfleet] 27 [1980]: 54-62). Toni Morrison describes her desire to "make you feel something profoundly ... to change and to modify" (Mari Evans, "Rootedness: The Ancestor as Foundation," in Black Women Writers [1950-1980]: A Critical Evaluation, ed. Mari Evans [Garden City, N.Y.: Doubleday, 1984], 339-45, esp. 341). 
story." Not surprisingly, this function is foregrounded in fiction that is most explicitly concerned with change. The feminist fiction that flourished in the late sixties and early seventies came out of a liberation movement, the so-called second wave of feminism in this century, and focused on women's efforts to liberate themselves from the structures of the past. As a literary movement it had certain similarities with Modernism: originating in a sense of the unprecedentedness of contemporary experience, it developed new fictional forms to express the "newness" of now; but it differed from Modernism in being part of a collective effort at social change and in viewing the past not (as some Modernists did) as a repository of lost value but as the source of-in Lessing's term-"something new." Though there are nostalgic tendencies in some feminist efforts to reclaim the past-in the search for women's cultures and communities, for lost matriarchies and goddesses-the novelists I am interested in critique nostalgia and disallow complacency about the past.

Feminist fiction is inherently unsettling, for by suggesting that a category as seemingly "natural" as gender is conventional and subject to change, it challenges established assumptions. Yet-as Rosalind Coward suggests-in order to distinguish between texts that have "a surface commitment to feminism" and those that have a deeper commitment, we must ask how "they achieve their versions of reality," "how representations work . . . how the text is constructed by writing practices and what ideologies are involved in it." ${ }^{5}$ The most revolutionary feminist fiction is so by virtue of textual practice as well as content, and is unsettling not only formally and structurally but in unsettling our relation to the past, in revealing the past as changing in response to the present and as capable of transforming present and future as well.

"What is it for, the past, one's own or the world's? To what end question it so closely?" asks the protagonist of Margaret Drabble's The Realms of Gold. ${ }^{6}$ In exploring memory in seventies feminist fiction, I will inquire why memory assumes particular importance

${ }^{4}$ Peter Brooks, Reading for the Plot: Design and Intention in Narrative (New Y rk: Vintage, 1985), 98, 235, 285. Roy Schafer, "Narration in the Psychoanalytic Dialogue," in On Narrative, ed. W. J. T. Mitchell (Chicago: University of Chicago Press, 1981), 25-49, refers to the goal of "narrative redescription" $(44,46)$. Michael S. Roth, Psychoanalysis as History: Negation and Freedom in Freud (Ithaca, N.Y: Cornell University Press, 1987), 124, also describes the transference process in these terms.

${ }^{5}$ Rosalind Coward, "Are Women's Novels Feminist Novels?" in The New Feminist Criticism: Essays on Women, Literature, Theory, ed. Elaine Showalter (New York: Pantheon, 1985), 225-39, esp. 228-29.

${ }^{6}$ Margaret Drabble, The Realms of Gold (New York: Knopf, 1975), 121. 
at particular cultural moments and suggest distinctions between memory and nostalgia. I am especially interested in works that thematize memory and reflect this concern narratively, metafictions that relate memory and liberation to questions of narrative (Doris Lessing's The Summer before the Dark [1973], Margaret Drabble's The Middle Ground [1980], Toni Morrison's Beloved [1987]) and Kunstlerromane that envision writing as the means of revising the past (Doris Lessing's The Golden Notebook, Margaret Laurence's The Diviners [1974], Margaret Atwood's Lady Oracle [1976]). Though metafiction, fiction that includes within itself commentary on its own narrative identity (as Linda Hutcheon defines it), is more often associated with postmodern (i.e., male) writers than with feminist writers, it is a powerful tool of feminist critique, for to draw attention to the structures of fiction is also to draw attention to the conventionality of the codes that govern human behavior-to reveal (as Patricia Waugh says) "how the meanings and values of [the] world have been constructed and how, therefore, they can be challenged or changed."7 Metafiction is "a process-oriented mode" (as Hutcheon suggests); it is also a transgressive mode (as Wallace Martin suggests), for when a writer talks about narrative within narrative, she unsettles traditional distinctions between reality and fiction and exposes the arbitrary nature of boundaries. ${ }^{8}$ Like the "women's writing" described by Mary Jacobus, feminist metafiction is "a process" played out across literary and ideological boundaries, a "transgression of literary boundaries" "that exposes those very boundaries for what they are-the product of phallocentric discourse," 9 though what Jacobus describes theoretically, I demonstrate as an actual practice in feminist metafiction.

$$
* * *
$$

Memory is our means of connecting past and present and constructing a self and versions of experience we can live with. To doubt it is to doubt ourselves, to lose it is to lose ourselves; yet doubt it we must, for it is treacherous. All Margaret Laurence's protagonists contend with it: in The Diviners, "memory-bank movies" play themselves through Morag's head; Stacey of The

Linda Hutcheon, Narcissistic Narrative: The Metafictional Paradox (New York: Methuen, 1984), 1, 6-7; Patricia Waugh, Metafiction: The Theory and Practice of Self-conscious Fiction (London: Methuen, 1984), 2, 34.

${ }^{8}$ Hutcheon, 6-7; Wallace Martin, Recent Theories of Narrative (Ithaca, N.Y.: Cornell University Press, 1986), 181.

'Mary Jacobus, “The Difference of View," in Women Writing and Writing about Women, ed. Mary Jacobus (New York: Barnes \& Noble, 1979), 12, 17. 
Fire-Dwellers (1969) is "conned into memory"; ninety-two-yearold Hagar of The Stone Angel (1964) is "rampant with memory."10 Sethe of Morrison's Beloved deplores her "devious" brain for "remembering the .... trees rather than the boys [hanging from them]. . . . She could not forgive her memory for that." "11 A character in Fay Weldon's Praxis (1978) reflects that "memory is a chancy thing, experience experienced, filtered coarse or fine according to the mood of the day, the pattern of the times, the company we happened to be keeping." 12 Memory revises, reorders, refigures, resignifies; it includes or omits, embellishes or represses, decorates or drops, according to imperatives of its own. Far from being a trustworthy transcriber of "reality," it is a shaper and shape shifter that takes liberties with the past as artful and lying as any taken by the creative writer.

In fact, memory is a creative writer, Mother of the Muses (Mnemosyne in Greek mythology), maker of stories - the stories by which we construct meaning through temporality and assure ourselves that time past is not time lost. By means of enabling fictions we make sense of our lives, and even "disabling" fictions, dysfunctional versions of the past that lock us into repetition of the past, make a kind of sense. When a disjunction occurs between our present reality and the stories we have created to explain how we got here-when our fictions lose explanatory force-we call this "crisis." Kate Armstrong of Margaret Drabble's The Middle Ground expresses midlife crisis in these terms: "I no longer trust my own memories. . . I I thought they made sense, that there was a clear pattern, but maybe I've got it all wrong, maybe there's some other darker pattern, entirely different"; "the past no longer seems to make sense, for if it did, how would it have left her here, in this peculiar draughty open space?"13 To lose the connection between past and present, as Kate has, is also to lose the narrative thread that supports her identity and reality: thus Drabble suggests parallels between Kate's crisis and problems of narrative construction. Kate will need to remember her past, or re-remember it ("rememory" it, in Morrison's coinage from Beloved $)^{14}$ in order to come up with a new story.

${ }^{10}$ Margaret Laurence, The Diviners (New York: Bantam, 1975), The FireDwellers (Toronto: McClelland \& Stewart-Bantam, 1969), 66, and The Stone Angel (New York: Bantam, 1981), 3.

"Toni Morrison, Beloved (New York: Random House, 1987), 6 (hereafter cited as B). For a discussion of memory and revision, see David Lowenthal, The Past Is a Foreign Country (Cambridge: Cambridge University Press, 1985), 206-10.

${ }^{12}$ Fay Weldon, Praxis (New York: Simon \& Schuster, 1978), 78.

${ }^{13}$ Margaret Drabble, The Middle Ground (New York: Bantam, 1980), 121, 10 (hereafter cited as $M G$ ).

${ }^{14}$ Morrison, 36, 95, 99, 160, 189, 201. 
The concern with memory surfaced in the early years of this century, with Modernist writers, and it emerged in response to crisis: with cultures, as with individuals, memory becomes problematic when continuity with the past is threatened. Early twentieth-century writers experienced their age as a time when the systems of the past-social, ethical, religious-lost explanatory force, and they expressed their sense of difference from the past in an intense interest in the past, an effort to understand the world that had been lost-to remember. Proust was obsessed with "time regained"; Woolf and Joyce were obsessed with time and memory, and so too were Eliot, Ford, and Faulkner, who tended to romanticize the past as a better place. ${ }^{15}$ In the decades subsequent to Modernism, British fiction was steeped in nostalgia: always the good days were the bygone days, first in a time before World War I, and then in a time before World War II. ${ }^{16}$ American literature also has its own intense, obsessive longings for a lost childhood innocence-for a lost southern past, for a frontier where men were men and women were women. ${ }^{17}$ Alicia Ostriker differentiates the poetry written by women in this century from that written by men: "It contains no trace of nostalgia, no faith that the past is a repository of truth, goodness, or desirable social organization. While the myth of a golden age has exerted incalculable pressure in the shaping of Western literature and its attitude toward history, the revisionist woman poet does not care if the hills of Arcady are dead. Or rather, she does not believe they are dead." 18

Nostalgia is a powerful impulse that is by no means gender specific. Everyone has longings to return home, which is what the word means: nostos, the return home. Even when the past is as horrendous as that described in Morrison's Beloved, the characters think back to "Sweet Home," the plantation they escaped from-“It

${ }^{15}$ See Shari Benstock, Women of the Left Bank: Paris, 1900-1940 (Austin: University of Texas Press, 1986), 24-36, for a discussion of nostalgic tendencies in Modernism; and Sandra M. Gilbert and Susan Gubar, No Man's Land: The Place of the Woman Writer in the Twentieth Century, vol. 1, The War of the Words (New Haven, Conn.: Yale University Press, 1988), 155-56, for nostalgia in Eliot.

${ }^{16}$ See chaps. 2 and 3 in Randall Stevenson, The British Novel since the Thirties: An Introduction (Athens: University of Georgia Press, 1986); and chap. 6 in Bernard Bergonzi, The Situation of the Novel (Pittsburgh: University of Pittsburgh Press, 1970), for discussions of nostalgia in postwar British fiction.

${ }^{17}$ R. W. B. Lewis, The American Adam: Innocence, Tragedy, and Tradition in the Nineteenth Century (Chicago: University of Chicago Press, 1955); and Leslie A. Fiedler, An End to Innocence: Essays on Culture and Politics (Boston: Beacon, 1948) discuss this aspect of American fiction.

${ }^{18}$ Alicia Ostriker, "The Thieves of Language: Women Poets and Revisionist Mythmaking," in Showalter, ed. (n. 5 above), 314-38, esp. 330. 
wasn't sweet and it sure wasn't home." "But it's where we were. all together. Comes back whether we want it to or not."19 But nostalgia has different meanings for men and women. Though from one perspective, women might seem to have more incentives than men to be nostalgic-deprived of outlets in the present, they live more in the past, which is why they are the keepers of diaries, journals, family records, and photograph albums-from another perspective, women have little to be nostalgic about, for the good old days when the grass was greener and young people knew their place was also the time when women knew their place, and it is not a place to which most women want to return. ${ }^{20}$ As Ostriker suggests, "Prufrock may yearn to be Hamlet, but what woman would want to be Ophelia?"21 Nostalgia is not only a longing to return home; it is also a longing to return to the state of things in which woman keeps the home and in which she awaits, like Penelope, the return of her wandering Odysseus. But if going back is advantageous to those who have enjoyed power, it is dangerous to those who have not. Thus Janice Doane and Devon Hodges describe nostalgia as "a frightening antifeminist impulse": "the nostalgia that permeates American politics and mass culture" is a desire for an imagined past that "authenticates woman's traditional place" when "men were men, women were women, and reality was real." 22

Besides, whatever nostalgic fantasies women have are less likely to be indulged than men's: quite simply, women are less likely to get to go home. At the end of John Fowles's Daniel Martin, Daniel steps back into a relationship left behind half a lifetime ago; at the end of William Kennedy's Ironweed the protagonist returns to "a nice little room" his wife has kept for twenty years; and at the end of Pat Conroy's The Prince of Tides the hero returns to a wife who has been patiently awaiting him. But such homecomings are rarely options for the woman, whose role is, rather, to wait and to keep the room waiting. Women's fiction often expresses a longing for a reconciliation with the mother (e.g., Woolf's To The Light-

${ }^{19}$ Morrison, 14-15.

${ }^{20}$ Rosalind Coward describes the way women function as "guardians of the unwritten history of the family," "attempting to record and capture transcient moments, to fix them and ensure their permanence," to "re-create an undamaged world ... where we have not encountered the pain of separation and loss" ("The Mirror with a Memory," in her Female Desires: How They Are Sought, Bought and Packaged [New York: Grove, 1985], 49-54, esp. 49-50, 53-54).

${ }^{21}$ Ostriker, 330.

${ }^{22}$ Janice Doane and Devon Hodges, Nostalgia and Sexual Difference: The Resistance to Contemporary Feminism (New York: Methuen, 1987), xiii. 
house, Lessing's The Diaries of Jane Somers), but this is not quite the same as the longing to return home. ${ }^{23}$

A character in Drabble's The Middle Ground recalls a sunny summer Sunday spent among friends ten years earlier in a time before their lives flew apart: "If we could have known. . . Well, would we have savoured it more? And were we really happy? Were we not, rather, half bored, and surreptitiously tormented by infidelities, unfulfilled ambitions, fatigue, financial anxieties.... Our minds more than half elsewhere... . No doubt all of us were suffering from sleepless nights and coughing children with earaches. If questioned, would we not then have looked back to the carefree days of youth, to ... Cambridge ... to love ... ? Yet, nevertheless, one can look back to such afternoons as though they possessed a true tranquility. In ten years will I look back upon myself sitting at this table and think, Ah, I was happy then?" ${ }^{24}$ The answer is Yes, you will look back and think "I was happy then," because there is something about memory that edits unpleasant details-the anxiety, irritation, fatigue, boredom, impatience, and pain of daily existence-in favor of the big picture, which is always done over with a flattering brush. Nostalgia is an uncritical acceptance of this rewriting, a view of the past as a foreign country where "they do things differently," in the celebrated opening line of L. P. Hartley's The Go-between-one of those nostalgic postwar British novels that laments a lost prewar innocence. ${ }^{25}$

It is not always easy to differentiate nostalgia from more productive forms of memory. But the roots of the words suggest different impulses: whereas "nostalgia" is the desire to return home, "to remember" is "to bring to mind" or "think of again," "to be mindful of," "to recollect." Both "re-membering" and "recollecting" suggest a connecting, assembling, a bringing together of things in relation to one another-which is why Woolf calls memory a "seamstress" who "run[s] her needle in and out, up and down,

${ }^{23}$ Few female protagonists return home, though the protagonist of Rita Mae Brown's Ruby Fruit Jungle is a notable exception. As Hélène Cixous says, “A boy's journey is the return to the native land, the Heimweh Freud speaks of, the nostalgia that makes man a being who tends to come back to the point of departure. . . . A girl's journey is farther-to the unknown" (Hélène Cixous and Catherine Clement, The Newly Born Woman [Minneapolis: University of Minnesota Press, 1986], 93). For a fascinating discussion of the loss of Eden in women's fiction as a loss of the mother, see Madelon Sprengnether, "(M)other Eve: Some Revisions of the Fall in Fiction," in Feminism and Psychoanalysis, ed. Richard Feldstein and Judith Roof (Ithaca, N.Y.: Cornell University Press, 1989), 298-322.

${ }^{24}$ Drabble, The Middle Ground (n. 13 above), 155.

${ }^{25}$ L. P. Hartley, The Go-between (London: Hamish Hamilton, 1953), 1. 
hither and thither." ${ }^{26}$ In fact, nostalgia and remembering are in some sense antithetical, since nostalgia is a forgetting, merely regressive, whereas memory may look back in order to move forward and transform disabling fictions to enabling fictions, altering our relation to the present and future.

$* * *$

Women especially need to remember because forgetting is a major obstacle to change. One of the most painful facts about the struggle for emancipation is that we have to keep starting it over again. This may be true of any effort at social change: each generation seems to need to make its own errors, and a kind of collective amnesia wipes out all memory of the struggles of the past. But anyone who teaches feminism today is struck by how quickly the struggle for women's rights has been forgotten: women's rights to vote, to hold property, to engage in certain types of work are taken for granted as God-given rights, with no sense of how recently they have been won, how much they cost. Nancy Cott refers to the "disremembering process" by which "feminism is aborted and repressed", ${ }^{27}$ Adrienne Rich refers to "the erasure of women's political and historic past" wherein the "history of women's struggle for self-determination has been muffled in silence over and over", ${ }^{28}$ Elaine Showalter notes that "each generation of women writers has found itself ... without a history, forced to rediscover the past anew, forging again and again the consciousness of their sex." ${ }^{29}$ The protagonist of Alix Kates Shulman's Burning Questions (1978) finds it "chilling ... that in only a few brief decades so much had been forgotten ... . it seemed that almost every idea we were now exploring ... had been delved by our predecessors. Delved, some even embraced by millions-and then somehow murdered and forgotten. How had it happened? We would have to find out ... so it couldn't happen again." She consoles herself that "even if the backlash were to eclipse us as it

${ }^{26}$ Virginia Woolf, Orlando (New York: Harcourt Brace \& Co., 1956), 78.

${ }^{27}$ Nancy F. Cott, The Grounding of Modern Feminism (New Haven, Conn.: Yale University Press, 1987), 274.

${ }^{28}$ Adrienne Rich, "Foreword: On History, Illiteracy, Passivity, Violence, and Women's Culture," in her On Lies, Secrets, and Silence: Selected Prose, 1966-1978 (New York: Norton, 1979), 9-18, esp. 11.

${ }^{29}$ Elaine Showalter, A Literature of Their Own: British Women Novelists from Brontë to Lessing (London: Virago, 1978), 11-12. See also Dale Spender, For the Record: The Making and Meaning of Feminist Knowledge (London: Women's Press, 1985), 2: "Unless we keep reminding each other of our heritage we endanger it, we risk losing it as we contribute to our own amnesia." 
had eclipsed all the earlier waves of feminism . . . when the next wave came (and they would keep coming, as they always had ... ) they' $\mathrm{d}$ find us there in the microfilm records . . . on library shelves, in feminist archives, a testament to our spirit." 30

We are now living through the second backlash against feminism in this century. The similarities between the first reactionwhich occurred immediately after women won the vote in the second decade-and the backlash today are indeed chilling. Once again women are sure that women's rights are all won; once again women yield to more urgent concerns-in the thirties, it was the Depression and preparations for a second world war; today it is the threat of the destruction of the planet that makes "the aims of Women's Liberation . . look very small and quaint," as Lessing, our foremost and most infuriating feminist writer, puts it (GN, ix). In fact the word "postfeminist," which sprang brilliantly to the pages of the New York Times in October 1982 and spoke so directly to a new generation of young women who imagined themselves beyond all that, ${ }^{31}$ was actually first used in 1919, when (as Nancy Cott tells us) "a group of female literary radicals in Greenwich Village" founded a new journal declaring an interest "in people ... not in men and women"; they called their stance "post-feminist." 32 Moving forward into the past, women forget; and worse than forgetting, they make "feminism" a dirty word, a "term of opprobrium," as Dorothy Dunbar Bromley said in $1927 .{ }^{33}$ By the 1950 s there were fewer women in higher education-fewer Ph.D.s, fewer women on faculties-than there had been in any decade since $1900 ;{ }^{34}$ and as Shulamith Firestone says, "all authentic knowledge of the old feminist movement by this time had been buried." 35 After the war, women were urged back into the home with the massive propaganda of the "feminine mystique," the results of which we know: the new cult of womanhood produced the malaise Betty Friedan named "the problem that has no name" and became the impetus for the resurgence of feminism..$^{36}$

${ }^{30}$ Alix Kates Shulman, Burning Questions (New York: Bantam, 1979), 270-71.

${ }^{31}$ Susan Bolotin, "Voices from the Post-Feminist Generation," New York Times Magazine (October 17, 1982).

${ }^{32}$ See Judy, vol. 1, no. 1 (June 1919), and Judy, vol. 2, no. 3 (1919) at the Arthur and Elizabeth Schlesinger Library on the History of Women in America, Radcliffe College, Cambridge, Mass. (quoted in Cott, 282, 365, n. 23).

${ }^{33}$ Quoted in William H. Chafe, The American Woman: Her Changing Social, Economic, and Political Roles, 1920-1970 (London: Oxford University Press, 1972), 92.

${ }^{3}$ Cott, 218.

${ }^{35}$ Shulamith Firestone, The Dialectic of Sex: The Case for Feminist Revolution (New York: Bantam, 1972), 27.

${ }^{36}$ Betty Friedan, The Feminine Mystique (1962; reprint, New York: Dell, 1983). 
So each time we take up the struggle for women's rights we have to begin anew. Maybe if the work is there "in the microfilm records," as Shulman says, some progress has been made, for in 1929 when Woolf wrote A Room of One's Own, the books she sought on the library shelves had not yet been written. ${ }^{37}$ Since then many have been written but many also have been lost, fallen out of print and into obscurity, and a major project of feminist scholarship continues to be the recovery of women's lost contributions. Feminism is a re-membering, a re-assembling of our lost past and lost parts of ourselves. We search for our mother's gardens, in Alice Walker's term; we search for our mothers-and this search (which is at times not easily distinguishable from nostalgia) figures prominently in contemporary women's fiction, as it does in feminist psychoanalytic theory, which pays new attention to the preoedipal stage of human development, excavating the mother buried by Freud's account.

In 1962, in The Feminine Mystique, Betty Friedan described the housewife's malaise as a loss of memory, of the ability to experience "the dimensions of both past and future." She compared housewives to men who had "portions of their brain shot away": "What they lost was . . . the ability . . . to order the chaos of concrete detail with an idea, to move according to a purpose ... tied to the immediate situation in which they found themselves . . they had lost their human freedom." Deprived of a "purpose stretching into the future [housewives] cannot grow [and so] lose the sense of who they are." ${ }^{38}$ So essential is "forgetting" to what they do that Lee Sanders Comer termed it the housewife's "only contribution to the world." 39

This explains why consciousness raising was-and is-crucial in feminist efforts. Consciousness raising is a re-membering, a bringing to mind of repressed parts of the self and experience. A recent project of "memory work" undertaken by the West German collective described in Frigga Haug's Female Sexualization makes clear the function of memory in change: "stepping back into the past, we embark upon a form of archaeology" that enables us to understand the processes that make us what we are and so to change what we are. By "memory work," the excavation of "ideologized" consciousness, we retrieve "elements of a new image of [self], on the basis of which [we] may possibly be able to construct

${ }^{37}$ Virginia Woolf, A Room of One's Own (New York: Harcourt, Brace \& Co., 1957), 46-59, 86-98.

${ }^{38}$ Friedan, 312-13.

${ }^{39}$ Comer (n. 1 above). 
alternatives for the future." 40 As Jane Flax suggests, “' 'new' memory

" is "a powerful impulse toward political action." 41

*** $*$

Early feminist fiction offers critiques like Friedan's of the amnesia imposed by women's roles, associating forgetting with repetition, and repression with regression. Esther of Sylvia Plath's The Bell Jar (1963) can only explain a woman's consenting to motherhood in terms of amnesia, and recalls her fiance's saying "in a sinister knowing way that after I had children I . . . wouldn't want to write poems any more. So I began to think maybe it was true that when you were married and had children it was like being brainwashed and afterward you went about as numb as a slave in some private, totalitarian state." ${ }^{42}$ Though Plath has her end "happily" adjusted to domesticity, this resolution is achieved by such willful blindness that one cannot help connecting Esther's repression with Plath's suicide a month after the novel was published. The protagonist of Fay Weldon's Praxis reads her mother's denial of an infidelity as repression: "At a time when women's instincts were so much at variance with the rules of society, such localized amnesias were only to be expected. But was this episode out of character; or was it that her whole life otherwise was out of character? Was my mother, from the age of thirty to the age of seventy, living out a part that did not suit her at all? I believe the latter." ${ }^{43}$ Norma Jean of Sheila Ballantyne's Norma Jean the Termite Queen (1975) laments that her adjustment to the housewife role has been "a homicide against the first and original self," though she also realizes that if she accomplishes this "transformation" into "someone else" she will have "no means to remember . . . and so perceive no loss": "when this happens to wives, it is not regarded as tragic, but natural." ${ }^{44}$ Norma Jean understands the difference between

${ }^{40}$ Female Sexualization: A Collective Work of Memory, ed. Frigga Haug and others, trans. Erica Carter (London: Verso, 1987), 48, 59, 49.

${ }^{41}$ Jane Flax, "Re-Membering the Selves: Is the Repressed Gendered?" Michigan Quarterly Review (“Women and Memory") 26, no. 1 (Winter 1987): 92-110, esp. 106. Other relevant essays in this collection are Mary Jacobus, "Freud's Mnemonic: Women, Screen Memories, and Feminist Nostalgia," 117-39; and Catharine R. Stimpson, "The Future of Memory: A Summary," 259-65.

${ }^{42}$ Sylvia Plath, The Bell Jar (New York: Bantam, 1981), 53, 69.

${ }^{43}$ Weldon (n. 12 above), 33.

"4 Sheila Ballantyne, Norma Jean the Termite Queen (New York: Doubleday, 1975), 194. 
regression and more productive forms of return to the past; she knows that returning to her husband's idea of her would be "to die the death that has no resurrection" whereas her own therapeutic methods of "reaching back in time" enable her to "touch an old, original self," to "get back a part of some original self which lay buried, deep as any pharaoh, all those years," to make "gestures associated with freedom." ${ }^{45}$

Lessing's A Proper Marriage (1952) powerfully describes the loss of self women undergo in pregnancy. Martha emerges at the end of each day "dazed. . . . Inside her stomach the human race had fought and raised its way through another million years of its history" ( $P M$, 113). As she is giving birth, she is stunned into forgetfulness, incapable of connecting pain with painlessness: "there were two states of being, utterly disconnected . . . and Martha . . . could not remember" $(P M, 144)$. When she emerges from her child's first few years to wonder what to do with the rest of her life, everyone-friends, family, husband, doctors-urges her to have a second child; and though her own amnesia conspires with their advice, "yet she did not altogether forget. And she did not choose to begin again" (PM, 252). Remembering is associated with choice.

Lessing is centrally concerned with memory because she is concerned with change-what enables it, what prevents it, what it accomplishes. Her critique of nostalgia in the early fifties, at a time when postwar British fiction was saturated in nostalgia, is remarkable indeed. Throughout The Children of Violence, Martha battles powerful nostalgic longings: "Nostalgia for what?" she wonders early in the series $(M Q, 22)$; "Nostalgia for something doomed," comes the answer (PM, 81). Lessing's novels document the diffculty of learning- "a lot of time, a lot of pain, went into learning very little" 46 - and the disastrous consequences of not learning. Martha's mother Mrs. Quest represents the effects of a lifetime of repression and demonstrates that those who deny the past are doomed to repetition and incomprehension. When she consults her photograph album for the meaning of her life, "her mind went dark, it kept going dark," against "something concealed, something she could not meet, did not know how to meet" (FGC, 239), areas of "congealed pain" (FGC, 285) to which she has no access. Martha, having "blocked off the pain" of the past, had "blocked off half of her life with it. Her memory had gone" $(F G C, 207)$; she is in danger of repeating this process; but in the final novels of the series, she

${ }^{45}$ Ibid., 128, 24, 128.

${ }^{46}$ Doris Lessing, The Summer before the Dark (New York: Bantam, 1973), 4 (hereafter cited as $S B D$ ). 
sets about "resurrect[ing] her lost past" (FGC, 215), "digging it out" (RS, 85), excavating the past so that she can move into "something new" (FGC, 69, 176). At the end of this excavation, she has transformed the past into "a landscape she could move into and out again," a place "she could visit, test-as one might dip a hand into water to see if it is too hot to bear"; "she could live again through this time, that time ... so that, if she wanted, the past enveloped, seeped through, the present" (FGC, 285). She has revitalized her past and made a connection with it that leads "her so much further than she had expected," opening "doors she had not known existed" (FGC, 285-86).

Martha's "work"- - undertaken, appropriately, in "the basement" - has implications for her entire culture, accomplishing no less than "a future for our race" $(F G C, 607)$. What is at stake in her quest for "something new" is more than individual freedom or fulfillment; it is the creation of a better world, an alternative to a death-bound society, a "four-gated city." Other feminist protagonists also find their personal survival linked to the collective life, though not usually so dramatically: Morag in Laurence's The Diviners finds her past intertwined with the history of Canada's earliest settlers; Frances in Drabble's The Realms of Gold (1975) discovers a kinship network that is surprisingly extensive; and individuals' lives in Drabble's The Ice Age (1979), The Middle Ground, and The Radiant Way (1987) are bound up with the collective life of England. Paule Marshall's The Chosen Place, the Timeless People (1969) and Maxine Hong Kingston's The Woman Warrior (1975) are similarly epic works that tell the stories of their cultures.

The protagonist's search for the past often takes the form of a journey home, a return to the family to confront mothers, fathers, grandparents, siblings, and cousins. In Atwood's Surfacing (1972) and Lady Oracle, in Drabble's Jerusalem the Golden (1967), The Realms of Gold, and The Radiant Way, and in Laurence's The Diviners, the protagonist looks in photograph albums-which are always kept by the mother-for clues about her past. Yet, as Carol P. Christ points out, women's quests tend to be vertical rather than horizontal: women dive, surface, $f l y{ }^{47}$ Besides this, they "divine," "excavate," dig in, dig out, and engage in various sorts of archeological projects. Toni Morrison describes Beloved as "a project of "literary archeology." "48 The speaker in Adrienne Rich's "Diving

${ }^{47}$ Carol P. Christ, Diving Deep and Surfacing: Women Writers on Spiritual Quest (Boston: Beacon, 1980). See also Jean E. Kennard, "Convention Coverage or How to Read Your Own Life," New Literary History 13, no. 1 (1981): 68-88, esp. 82.

${ }^{48}$ Quoted in Colin Walter's review of Beloved, "A Ghostly, Terrifying Tale of Lives in Slavery," Insight (October 12, 1987). 
into the Wreck" embarks on an underwater archeological expedi. tion, seeking in the "book of myths in which / our names do not
appear" "the thing itself and not the myth." 49 Woolf"s Orlando
"dislodges" memories that are "cumbered with other matter lith "dislodges" memories that are "cumbered with other matter like the lump of glass which, after a year at the bottom of the sea, is grown about with bones and dragon-flies coins and the tresses of drowned women." ${ }^{50}$ Frances in Drabble's The Realms of Gold is an archaeologist by profession; Lesje in Atwood's Life before Man (1979) is a paleontologist; the protagonist of Rebecca Hill's Among Birches (1986) describes herself as "such a good archaeologist... poking among the ruins, trying to restore from fragments all that had been lost. Men didn't do this; they dropped socks. Territory mattered, not history." ${ }^{11}$ Laurence's diviner-artist "undertakes the undertaker" in excavating the story of the undertaker as well as other buried lives. ${ }^{52}$ The protagonist of The Middle Ground is inspired to remember by the smell of sewage wafting up from subterranean passages, a smell she compares wryly to that of Proust's madeleine. ${ }^{53}$

Most of Atwood's protagonists undertake projects of excavation, In Surfacing, the protagonist's search for her missing father takes her on a kind of underwater archaeological expedition; diving beneath the "surface" of the lake in search of his body, she makes discoveries that allow repressed memories to "surface" and she "surfaces" too, in possession of more than she knew she had lost-her past and herself. In Bodily Harm (1982), the central image is "digging" it out (or up): Rennie describes her background as "less like a background . . . than a subground, something that can't be seen but is nevertheless there, full of gritty old rocks and buried stumps . . . nothing you'd want to go into. Those who'd lately been clamoring for roots had never seen a root up close, Rennie used to say." ${ }^{4}$ Though Rennie tries to stay on the "surfaces," her mastectomy forces her to "go into" harsh truths both personal and political, to confront "malevolence" that is more than "bodily" and become a "subversive" in the end..$^{55}$

$$
* * *
$$

${ }^{49}$ Adrienne Rich, Diving into the Wreck: Poems, Selected and New, 1950-1974 (New York: Norton, 1975), 197-98.

${ }^{50}$ Woolf, Orlando (n. 26 above), 101.

${ }^{51}$ Rebecca Hill, Among Birches (New York: Viking Penguin, 1987), 130.

${ }^{52}$ Laurence, The Diviners (n. 10 above), 399.

${ }^{53}$ Drabble, The Middle Ground (n. 13 above), 109.

${ }^{54}$ Margaret Atwood, Bodily Harm (New York: Simon \& Schuster, 1982), 22-23.

${ }^{55}$ Ibid., 265. 
Doane and Hodges define nostalgia as "not just a sentiment but also a rhetorical practice." Their definition makes clear the relation of nostalgia to textual practice: the past that is longed for is a place within discourse where the referent referred to something "real," "a past in which women "naturally' function in the home to provide a haven of stability that is linguistic as well as psychic." 56 In a nostalgic mode-and Christopher Lasch's The Culture of Narcissism is exemplary-the referent is seen "as an authentic origin or center from which to disparage the degenerate present," a present in which literary texts no longer represent "the real world": "the battleground is representation itself." 57 Doane and Hodges urge feminists to "undermine nostalgic rhetoric" by "leaving cultural definitions of masculinity and femininity in play, rather than in place." 58

Textual feminists subvert "nostalgic rhetoric" by mining the past to discover play rather than place. They suggest a view of the past not as fixed and finished but as so vitally connected to the present that it takes on new meaning in response to present questions and needs. As Laurence's Morag says, “a popular misconception is that we can't change the past-everyone is constantly changing their own past, recalling it, revising it." ${ }^{59}$ As Maxine Hong Kingston suggests, "the reason we remember the past moment at all is that our present-day life is still a working-out of a similar situation"; "understanding the past changes the present. And the ever-evolving present changes the significance of the past." ${ }^{\prime \prime 0}$ Such questions have also been raised by contemporary philosophy of history, which is similarly concerned with understanding how the present determines our view of the past-with what Michael S. Roth calls "the presentist aspects of . . . historical inquiry." 61

In novels by Lessing, Drabble, Laurence, Atwood, and Morrison, protagonists begin with a longing for "the true story," something real to which referents attach, which they relinquish for a view of the past as ever-changing and open to revision-a view they

${ }^{56}$ Doane and Hodges (n. 22 above), 14.

${ }^{57}$ Ibid., 8, 9-10, 3.

${ }^{58}$ Ibid., 142.

${ }^{59}$ Laurence, The Diviners, 60.

${ }^{60}$ Paula Rabinowitz, "Eccentric Memories: A Conversation with Maxine Hong Kingston," Michigan Quarterly Review ("Women and Memory") 26, no. 1 (Winter 1987): 177-87, esp. 179.

${ }^{61}$ Roth (n. 4 above), 123, cites literature on the role of the present in the writing of the past: e.g., R. G. Collingwood, The Idea of History (Oxford: Oxford University Press, 1946); and Hayden V. White, Metahistory: The Historical Imagination in Nineteenth Century Europe (Baltimore: Johns Hopkins University Press, 1978). See also Lowenthal (n. 11 above), 210-24, 324-64. 
find enormously liberating, for if the past is a construct, it can be reconstructed. Laurence's Morag tries to remember "what really happened," contemplates the meanings of the family photographs ("I am remembering myself composing this interpretation"; "I don't even know how much of that memory really happened and how much of it I embroidered later on") and comes to realize that "what really happened" is not only not knowable but also not important-“a meaningless question. But one I keep trying to answer, knowing there is no answer." When she can acknowledge that what matters is the process of remembering, "the necessary doing of the thing- that mattered," she can assume the "authority" of "authorship" and "set down her title," the "title" of the novel we have just read-The Diviners. ${ }^{62}$

The sense of the past as evolving in confrontation with the present is mirrored in the narrative strategies of feminist fiction. Even in the most straightforward of these novels, chronology is disrupted, as it is in much contemporary and Modernist fiction. But one structure-the pattern of circular return-recurs with such frequency as to be practically a defining characteristic. ${ }^{63}$ In novels as diverse as Atwood's Lady Oracle, Drabble's The Waterfall (1969), Fay Weldon's Praxis, Gail Godwin's The Odd Woman (1974), Erica Jong's Fear of Flying (1973), Lisa Alther's Kinflicks (1975), Ursula K. Le Guin's The Dispossessed (1974), and Anne Tyler's Earthly Possessions (1977), episodes set in the past alternate with episodes set in the present until, in the end, past becomes present; variations of this occur in Anne Richardson Roiphe's Up the Sandbox (1970), Marge Piercy's Woman on the Edge of Time (1976), Atwood's Handmaid's Tale (1986), and in "self-begetting novels" ${ }^{4}$ that end with the protagonist ready to write the novel we

${ }^{62}$ Laurence, The Diviners, 8, 17-18, 60, 452-53.

${ }^{63}$ Antilinearity is by no means unique to women's fiction, as Patricia Drechsel Tobin's discussion of assaults on linearity in modern fiction suggests (Time and the Novel: The Genealogical Imperative [Princeton, N.J.: Princeton University Press, 1978], 27). For associations of the female and the cyclic, see Julia Kristeva, "Women's Time," trans. Alice Jardine and Harry Blake, Signs: Journal of Women in Culture and Society 7, no. 1 (Autumn 1981): 13-35; Robbie Pfeufer Kahn, "Women and Time in Childbirth and during Lactation," Taking Our Time: Feminist Perspectives on Temporality, ed. Frieda Johles Forman with Caoran Sowton (Elmsford, N.Y: Pergamon, 1988), 20-36, esp. 25; and Susan Gubar, "The Representation of Women in Fiction," in Selected Papers from the English Institute, ed. and intro. Carolyn G. Heilbrun and Margaret R. Higonnet, N.S., no. 7 (Baltimore: Johns Hopkins University Press, 1981), 19-59, esp. 31. I discuss circular structures in women's novels in my forthcoming book on feminist fiction, Breaking the Circle: Feminist Fiction and the Tradition (Bloomington: Indiana University Press, 1991).

${ }^{64}$ So termed by Steven G. Kellmann, "The Fiction of Self-begetting," Modern Language Notes 91 (December 1976): 1234-56, esp. 1245. 
have just read-The Diviners and The Golden Notebook. The alternation of past and present episodes draws attention to the vital interaction of past and present and allows a circling back over material that enables repetition with revision; final scene returns to first scene, with the difference between them providing measure of change, of a present transformed by remembering. The simultaneous backward and forward movement permits us "to read time backward" (in Paul Ricoeur's phrase) insofar as is possible on one reading; for though the linear sequence of language commits us to reading forward, understanding requires rereadings and depends on knowledge of the end. Ricoeur describes the experience of narrative in these terms: "By reading the end into the beginning and the beginning into the end, we learn to read time backward. ... In this way, the plot does not merely establish human action 'in' time, it also establishes it in memory. And memory in turn repeats-re-collects-the course of events." ${ }^{65}$

In a sense, women's fictions have always been circular. In traditional fictions by and about women, women exchange "one domestic space for another" (in Elizabeth Abel's phrase), an exchange which reflects "the creative cul-de-sac of the romantic mode" (in Helene Moglen's term) where "marriage leads back to Victorian patriarchy rather than forward to a mature female identity" (in Karen Rowe's term). ${ }^{66}$ When-as in Lessing's The Grass Is Singing (1950) and A Proper Marriage (1952) - the repetition of the mother's life is a "nightmare," the return to the beginning is a vicious circle representing the triumph of the past; but in Lessing's later fiction and in fiction by Drabble, Atwood, and Laurence, the circular structure represents a return that leads not back but forward, becoming means to a transformed present and future, allowing repetition in order for there to be escape from repetition, in order for there to be change. In The Four-Gated City (1969), Martha's circular return enables her to relearn what she has forgotten and to assimilate knowledge on deeper levels: "That is what learning is. You suddenly understand something you've understood all your life, but in a new way" ( $F G C, 97)$. This novel transforms the closed circle of repetition into cyclic returns that allow memory work or "re-collection": "Yes, forgetting, forgetting again and again, life brings one back to points in oneself . . . over

${ }^{65}$ Paul Ricoeur, “Narrative Time,” in Mitchell, ed. (n. 4 above), 165-86, 179.

${ }^{66}$ Elizabeth Abel, Marianne Hirsch, and Elizabeth Langland, eds., The Voyage In: Fictions of Female Development (Hanover, N.H.: University Press of New England, 1983), 8. Helene Moglen, as quoted in Karen E. Rowe, " 'Fairy-born and Human Bred': Jane Eyre's Education in Romance,” in Abel, Hirsch, and Langland, eds., $69-89$, esp. 84 . 
and over again in different ways, saying without words: This is a place where you could learn if you wanted to. Are you going to learn this time or not? No? Very well then, I'll . . . find ways of bringing you back to it again. When you are ready, then" (FGC, 472).

In feminist Kunstlerromane, the protagonist's writing is her means to liberation. In Lady Oracle, Atwood contrasts a fictional form that entraps, the Gothics Joan writes for a living, to a mode that liberates, represented by Atwood's novel as a whole. Joan's Gothics promise escape, but they actually recycle the past in a dead end of repetition that leaves her trapped; like the junk food she is also addicted to, they provide a momentary high in exchange for a long-term letdown: "You can't change the past, oh, but I wanted to. . . . That was the one thing I really wanted to do." But as she begins to unravel the snarl of past, and her strategies of containmentpsychological and literary-begin to break down, the Gothic formula ceases to function even as temporary relief. At the end she is left contemplating more future-oriented modes- "I won't write any more Costume Gothics . . . I think they were bad for me. But maybe I'll try some science fiction. The future doesn't appeal to me as much as the past, but I'm sure it's better for you." ${ }^{\prime \prime}$ Whether Joan does go on to more progressive forms, Atwood herself has forged a form which, by delving into the past, explodes conventional containments and breaks the hold of repetition.

Lessing's The Golden Notebook is, of all these texts, the most extensive exploration of questions of memory, narrative, and liberation. Anna has vowed never to write fiction again, she is so appalled by the "lying nostalgia" (GN, 63) of her best-selling first novel, The Frontiers of War. All her efforts "to write the truth" leave her "realising it's not true" (GN, 274): "How do I know that what I 'remember' was what was important? What I remember was chosen by Anna, of twenty years ago. I don't know what this Anna of now would choose" (GN, 137). She longs for a concrete, knowable "truth," but her every attempt at a "straight, simple, formless account" (GN, 63, 229) throws her back on memory. She imagines that visual images will provide greater certainty- "the absolute assurance of a smile, a look, a gesture, in a painting or a film” (GN, 110); "probably better as a film. Yes, the physical quality of life... not the analysis afterwards" (GN, 228)-but comes to realize that the visual image is as dependent upon memory as the verbal is: "What makes you think that the emphasis you have put on it is the correct emphasis?” (GN, 619). All representation throws her back

${ }^{67}$ Margaret Atwood, Lady Oracle (New York: Avon, 1976), 6, 379. 
on the shaping, ordering, selecting faculty of the mind and, ulti-

However, Anna comes to understand memory as the means to change. The reworking of material in the four notebooks and two novels she is writing allows her to go over her life again and again until she can get it right-to repeat, re-vise, to "name in a different way" (GN, 616).$^{68}$ Every important event, issue, question, quality, action, attitude, gets redefined in the course of the novel; everything essential comes up for re-naming as, in the visionary and re-visionary episodes of the fifth notebook-the golden notebookthe value of "boulder pushing," of "taking a stand," of "the forms," of "making patterns," irony, and "naming" itself-all are re-named as Anna wrests "out of the chaos, a new kind of strength" (GN, 467). "Preserving the forms" and "just making patterns," for example, are first viewed as cowardly limitations, but then are re-envisioned as acts of the creative imagination (GN, 26, 275, 634); "naming" itself is first seen as a fatal "fixing," "a 'naming' to save . . f from pain" $(G N, 489)$, but it too becomes identified with the creative, transformative imagination.

When Anna can accept that there is no reality apart from the mind that perceives it and the language that expresses it, she can accept that none of her versions is "true"-or all are "true," or "truth" itself is a fiction, invented rather than discovered. Not that there is "no reality," as in extreme versions of poststructuralist thought, but that "truth" is a process, in the patterning rather than the "patterns." ${ }^{9}$ Having accepted that "the story of my life" can

${ }^{65}$ Judith Kegan Gardiner, "Female Identity and Writing by Women," Critical Inquiry ("Writing and Sexual Difference," ed. Elizabeth Abel) 8, no. 2 (Winter 1981): 347-61, esp. 359, suggests that "the repetitive, overlapping style of the novel imitates [the] process of remembering, as the narrator writes and reads herself, creating and discarding partial and alternative selves." Noting that "Anna's effort to retain her memories . . . keeps her personality intact and saves her from madness," Gardiner speculates that "male memory operates differently from female memory. ... Men maintain a coherent sense of themselves by repression" (358-59). I discuss various forms of male repression in the novel in "Women and Men in The Golden Notebook: Divided Selves," in The [M]other Tongue: Essays in Feminist Psychoanalytic Literary Interpretation, ed. Shirley Nelson Garner, Madelon Sprengnether, and Claire Kahane (Ithaca, N.Y.: Cornell University Press, 1985), 280-305.

${ }^{69}$ Roberta Rubenstein, The Novelistic Vision of Doris Lessing: Breaking the Forms of Consciousness (Urbana: University of Illinois Press, 1979), 102, 74, notes that Lessing provides "no single authoritative view of events" and suggests that "objectivity is an aesthetic and epistemological convention." Betsy Draine notes that when Anna is "no longer bound to find the truth [she] is free to present her truth, with renewed conviction" ("Nostalgia and Irony: The Postmodern Order of The Golden Notebook," Modern Fiction Studies 26, no. 1 [Spring 1980]: 31-48, esp. 46). 
never be more than "a record of how I saw myself at a certain point" (GN, 473), Anna is free to re-member and to re-vise. When she can relinquish her longing for "the true story," she can accept that she has written the novel we have just read, allowing her various versions, however "crude, unfinished, raw, tentative" (GN, 236), to come together into "something new." The Golden Notebook is a writerly text that (in Roland Barthes's terms) admits to its own uncertainties and contradictions, to its processes of production, and by involving the reader in those processes, allows "something new." ${ }^{70}$ Like The Children of Violence, The Golden Notebook is concerned with the consequences of repressing, but here it is the male characters who block off, "stay cool," and are frozen in postures that make them incapable of change, whereas Anna's ability to stay open and enter experiences beyond her own enables her to break through to "something new." Though Lessing's early fiction gave us the word "matrophobia,"71 The Golden Notebook finds value in female boundary confusion and relatedness, anticipating feminist revisionists Nancy Chodorow, Dorothy Dinnerstein, Jane Flax, Carol Gilligan, and Jean Baker Miller, who reinterpret female identity positively. ${ }^{72}$

Similarly, protagonists of Lessing's and Drabble's midlife identity crisis novels, The Summer before the Dark and The Middle Ground, discover that there is no one right "pattern." Lessing's Kate Brown seeks "the truth, whatever that was," "what she really felt" beneath the "worn" and "stereotyped" attitudes "custom allots" (SBD, 1-2), for she has come to realize that her image of herself and her marriage is "out of date"- that rather than being "the warm centre of the family," she has been "starved" by her

${ }^{70}$ Barthes contrasts the "readerly" mode of realism which is "product" and "can only be read" and, inscribed within ideology, is incapable of accommodating change, with the "writerly text" which, as process and capable of being "written" or "produced," is open to "play" and capable of accommodating change (S/Z [New York: Hill \& Wang, 1974], 4-5).

${ }^{71}$ The term was coined by Lyn Sukenick in "Feeling and Reason in Doris Lessing's Fiction," in Doris Lessing: Critical Studies, ed. Annis Pratt and L. S. Dembo (Madison: University of Wisconsin Press, 1974), 98-118, esp. 102-as noted by Judith Kegan Gardiner, “A Wake for Mother: The Maternal Deathbed in Women's Fiction," Feminist Studies 4, no. 2 (June 1978): 146-65, esp. 164.

${ }^{72}$ Nancy Chodorow, The Reproduction of Mothering: Psychoanalysis and the Sociology of Gender (Berkeley: University of California Press, 1978); Dorothy Dinnerstein, The Mermaid and the Minotaur (New York: Harper \& Row, 1976); Jane Flax, "The Conflict between Nurturance and Autonomy in Mother-Daughter Relationships and within Feminism," Feminist Studies 4, no. 2 (June 1978): 171-89; Carol Gilligan, In a Different Voice: Psychological Theory and Women's Development (Cambridge, Mass.: Harvard University Press, 1982); Jean Baker Miller, Toward a New Psychology of Women (Boston: Beacon, 1976). 
children's indifference and her husband's infidelities (SBD, 52). Her quest leads her to repudiate the conventions that have governed her behavior as a woman: her conditioning as a sexual object now strikes her as "rubbish," "nonsense," "a con job," "a bloody waste of time" (SBD, 196), "a load of shit" (SBD, 200); and motherhood itself seems a "long, grinding process" which has turned "an unafraid young creature" into "an obsessed maniac" and then cast her off "like an old nurse" (SBD, 94).

The way back from these bleak insights is through "rememory" elicited in response to another person. By forming a friendship with a younger woman, a stranger, entering into a surrogate motherdaughter relationship of the sort that Lessing often shows as more liberating than family ties are, Kate re-remembers. Confronted by Maureen's matrophobia, she can defend Maureen's mother for "bringing you up, and making not a bad job of it" (SBD, 205); and in response to Maureen's "tell me a story," she finds memories that allow her to modify her view of her marriage "as a web of nasty self-deceptions" (SBD, 232): "It almost seemed as if the things she remembered were because of Maureen's interest-Maureen's need?" (SBD, 222) — a suggestion developed by Morrison in Beloved, of the therapeutic value of memory recalled in response to the needs of others. But Kate's realization that "what she really feels" is inconclusive and provisional-that "in a year or so's time" her experience of the summer "would not seem anything like it did now" (SBD, 232) —enables her to relinquish her quest for "the truth." Such discoveries turn out not to be particularly liberating, however, since she is unable to conceive of alternatives to the situation from which she began, and her most important lesson is to say "no": "her experiences of the last months, her discoveries, her self-definition; what she hoped were now strengths, were concentrated here ... she was saying no: no, no, no, NO" (SBD, 144). Lessing envisions female "boundary confusions" as mere liabilities in this novel, and Kate ends by returning to the domestic situation that has been the source of the problem, in a closed circular return consistent with the bleak view of motherhood.

Drabble's The Middle Ground revises Lessing's midlife crisis novel, turning the "shit" which seemed to Kate Brown the essence of life, to "gold"- which is Kate Armstrong's term for her uncanny knack of transforming the raw materials of life to empowering art forms $(M G, 19)$. Drabble's Kate begins where Lessing's Kate began, in a spirit of self-repudiation, only her disgust extends to women generally: "I'm . . . bloody sick of bloody women, I wish I'd never invented them" $(M G, 2)$. Kate has "invented women" in that her journalism has helped make the women's movement, but now, 
having attained the goal of "women's liberation" and become a "free woman" (MG, 49, 59, 65, 66), she finds her "freedom" turned to "a narrow tunnel" and herself "trapped in stale repetition" (MG, 52), "locked in a bad circle" ( $M G, 66)$, "come to a dead end" (MG, $52-53)$. Kate's loss of a version of the past which makes sense of the present and a version of the present which makes sense of the past causes her to question the future: "If it is a mid-life crisis ... what on earth is on the other side of it?" (MG, 10). She no longer believes in "freedom" or "progress," for herself or anyone else: "her implacable progress has been halted, a link has been broken" (MG, 10), and she now feels that freedom is "bad for people" $(M G, 5)$. She is, moreover, overwhelmed by confusion-“"when one was younger, one saw patterns everywhere, for the process of selection was so simple" (MG, 172), but now her self, her past, present, future, even the environment, seem to require "re-interpretation" (MG, 44).

"Re-interpretation" is enabled by a trip home. One of the things Kate is feeling as she sets out for Romley is that there is no connection between her past and present selves, "no blood flowed from one to the other, the cord was cut, she withered and grew dry" (MG, 109) - an image suggesting that such severance is death. "Connection" is enabled by the "strange distracting smell" of the sewage, which, rising from "the mysterious network of drains and pipes and tubes and gulleys and sewers"-a network associated with the "underworld," "the underground"-releases memories: "no revelations ... just memories" (MG, 107-8). As in Woolf"s fiction, "the great revelation" never comes; ${ }^{73}$ rather, small "illuminations" occur in the form of Kate's seemingly random reflections about her past, her brother, her parents: "For she had loved these two terrible people, in the dawn of time, in the dark before dawn, in the underground she had loved them. And nothing in her conscious self, in her daylight self, had been able to love. Was this the problem, was this the fault?" (MG, 108-9). She fears that it is this which has distorted her relations with everyone ever after, leaving her damaged like her brother Peter who, for all his heroic will to change, remains twisted in his depths, locked into "some other darker pattern" which is incomprehensible, uncontrollable, unchangeable $(M G, 121)$ : "there was no denying it, the idea of Peter was inextricably linked in her mind with whatever it was that had gone wrong with her own life"; "there he was, standing in her mind like a dam in a river" $(M G, 116)$.

${ }^{73}$ In pt. 3 of To the Lighthouse, Lily, pondering "the meaning of life," speculates that "the great revelation perhaps never did come. Instead there were little daily miracles, illuminations, matches struck unexpectedly in the dark" (New York: Harcourt Brace \& Co., 1955), 240. 
But Kate must go further, to confront the possibility that it was she who damaged him. Contrary to what she initially asserted, that "every single bad thing that's happened to me happened to me because I'm a woman" $(M G, 5)$, "some other . . pattern" emerges that suggests that it was being a woman that enabled her to survive. Peter was "the real victim" of her parents, "being the only boy." Her father "had nagged at Peter to better himself. . . . And Peter had been terrorised. . . . A sacrifice to progress" (MG, 110-11). She now senses that her refusal to compete, her "backhanded," "sinister female game" (MG, 122), made her complicit with what destroyed him, which suggests that she will need to forgive herself for being female before she can regain equanimity about women generallyand though this realization never quite surfaces, Drabble suggests the workings of subterranean processes too deep to articulate, rendering them imagistically: "The dirty, tangled roots of childhood twisted back forever and ever, beyond all knowing. Impacted, interwoven, scrubby, interlocked, fibrous, cankerous, tuberous, ancient, matted" (MG, 122). Though the damage cannot be undone, to Kate or to Peter, and though the imagery suggests that beneath this pattern may be another and another, extending back infinitely, unknowable, unfathomable, for now, for the present, currents are set flowing that establish a revitalizing link between past and present.

Though nothing has changed in the end except Kate's perspective, Kate has come through her crisis and ends at "the centre of a circle" of family and friends, a circle she has created by taking in and including all sorts of people of various classes, countries, and races: "Looking around her family circle, feeling as she sat there a sense of immense calm, strength, centrality, as though she were indeed the centre of a circle . . . but imagine a circle . . . a circle and a moving sphere, for this is her house and there she sits, she has everything and nothing, I give her everything and nothing" ( $M G$, 255). This is not a vicious circle of determined behavior, but an image of harmony and inclusiveness that accommodates change"Anything is possible, it is all undecided. . . . Nothing binds her, nothing holds her" (MG, 257). Whereas Lessing consigns her protagonist to the situation from which she began, Drabble leaves her Kate "confronted by choice." Whereas Kate Brown protects herself by saying no, for Kate Armstrong "saying yes is my special technique for preserving myself. . . . I don't know why it works, but it does" $(M G, 8)$; and her female boundary confusions and connections with others are affirmed as sources of strength and salvation.

The narrative structure of this novel is itself affirmation that the self is created through relationship: Drabble's use of a narrator who 
pieces the story together from the interpretations of Kate and Kate's friends invites the reader to participate in the creation of meaning and, in imaginative collaboration with the reader, confers value"gives"-is confirmation of the value of community and communication. Like The Golden Notebook, The Middle Ground is a writerly text that might also be termed a "feminine text" in that the "female" qualities that enable the protagonist to change are also qualities of writerly narrative: openness, sympathetic participation, and process are not only central values that are represented by the protagonist but also they are affirmed by narrative form.

\section{$* * *$}

Though Morrison's Beloved is concerned with the liberation of the black community rather than the white, middle-class woman, this writerly text which depicts memory and narrative as means to liberation has affinities with feminist metafiction by Lessing, Laurence, Drabble, and Atwood.

The past that lies behind the action of Beloved is a "nightmare" which is by no means past: the "sixty million and more" victims of the diaspora to whom the novel is dedicated, "the black and angry dead" $(B, 198)$, seize the present and possess it in the form of the murdered baby's ghost-“what a roaring" $(B, 181)$. This is a world in which "anybody [you] knew, let alone loved, who hadn't run off or been hanged, got rented out, loaned out, bought up, brought back, stored up, mortgaged, won, stolen or seized" $(B, 23)$; "so you protected yourself and loved small" $(B, 162)$. "Reconstruction" is more than the period in which the novel is set: it is the task the characters face as they set about rebuilding the culture that has been decimated by slavery, learning how to love and trust and make the connections with others that will enable them to go on.

Silenced, isolated, loving small, they are at first determined to forget. Sethe "worked hard to remember as close to nothing as was safe" ( $B, 5-6)$ and not to "go inside" $(B, 46)$; Paul D has "shut down a generous portion of his head" $(B, 41)$. But the refusal to confront the pain of the past keeps the past continually alive, as Sethe's "talking about time" suggests: "I mean, even if I don't think it, even if I die, the picture of what I did, or knew, or saw is still out there. Right in the place where it happened . . . someday you be walking down the road and you hear something or see something going on. . . . And you think it's you thinking it up. . . But no. It's when you bump into a rememory that belongs to somebody else.... It's never going away. ... The picture is still there and what's more, if you go there-you who never was there-if you go 
and stand in the place where it was, it will happen again; it will be there for you, waiting for you.... Because even though it's all over-and done with-it's going to be always there waiting for you" $(B, 35-36)$. Her daughter Denver gets the point: " 'If it's still there, waiting, that must mean that nothing ever dies.' Sethe looked right in Denver's face. 'Nothing ever does,' she said"' $(B, 36)$.

The idea that everything that's ever happened is still somewhere out there is truly terrifying: it clogs the world with the past, with our own and everyone else's, and allows the past to possess the future as well as the present. But this is an expression of Sethe's cathected imagination, a mind "loaded with the past" and "no room to imagine, let alone plan for, the next day" $(B, 70)$, as Sethe herself says.

However, Morrison shows that even a past as horrific as this is not fixed but is open to revision by "rememory."74 Beloved is about bringing what's dead to life, which "hurts," as Denver knows ( $B$, 35 ); and dead parts come back to life in response to other people. When at the beginning of the novel Paul D meets Sethe after many years, "the closed portion of his head opened like a greased lock" $(B, 41)$; and his arrival prompts her to think about "plans" ("Would there be a little space ... a little time ... to . . . trust things and remember things" $[B, 18])$, to give into "the temptation to trust and remember ... to go ahead and feel. ... Go ahead and count on something" $(B, 38)$. Memory is linked to trust-for the third time-when she expresses her desire "to have him in her life": "Trust and rememory, yes. .. . The mind of him that knew her own. Her story was bearable because it was his as well-to tell, to refine and tell again. The things neither knew about the other-the things neither had word-shapes for-well, it would come in time" $(B, 99)$. The association of trust and rememory suggests a connection between going inside and reaching outside, between risking the pain and confusion of going within and having the confidence that someone will be there: Sethe can risk remembering because she can trust that Paul D will (as he says) "hold [her] ankles" while she "goes inside" ( $B, 46)$.

Beloved is another "dead thing" that "comes to life," and though her return is sinister, it also allows an exorcism. One of the good things she inspires is "telling": hungry for stories, Beloved gets

${ }^{74}$ Morrison describes her interest in "ways in which the past influences today and tomorrow" (Los Angeles Times [October 14, 1987]) and refers to her writing generally as a way of "sorting out the past," of identifying "those things in the past that are useful and those things that are not" (Thomas Le Clair, "The Language Must Not Sweat': A Conversation with Toni Morrison," New Republic [March 21, 1981], 75-78, esp. 75-76). 
Sethe to "feed her" with stories, and Sethe (like Lessing's Kate) is astonished to find "pleasure" in remembering: "It amazed Sethe . . . because every mention of her past life hurt. Everything in it was painful or lost ... unspeakable. ... But, as she began telling she found herself wanting to, liking it . . . in any case it was an unexpected pleasure" $(B, 58)$.

Beloved is also the story of Denver, a strange, lonely girl who learns early her mother's lesson of repression, going "deaf" rather than hear the truth which Nelson Lord tries to tell her $(B, 104)$. When the ghost returns in the form of Beloved, she initially welcomes its companionship, but when the haunting gets out of control, she realizes that she will have to go out into the world and "ask somebody for help" ( $B, 243)$. At first she is paralyzed by memory and stands frozen on the porch, immobilized by her mother's and grandmother's warnings: "Out there were places in which things so bad had happened that when you went near them it would happen again. Like Sweet Home where time didn't pass and where, like her mother said, the bad was waiting for her as well ... Grandma Baby said there was no defense" (B, 243-44). But at this point another kind of rememory comes to her rescue: "And then Baby Suggs laughed, clear as anything"-_You mean I never told you nothing about Carolina? About your daddy? You don't remember nothing about how come I walk the way I do and about your mother's feet, not to speak of her back? I never told you all that? Is that why you can't walk down the steps? My Jesus my." "But you said there was no defense." "There ain't." "Then what do I do?" "Know it, and go on out the yard. Go on" $(B, 244)$. Denver gets herself out of the yard, but soon realizes that nobody is going to help her unless she "told it-told all of it" $(B, 253)$.

The community responds to her pleas, reversing its former hostility with acts of caring. The final part of the novel offers several such reversals, repetitions of earlier events or situations with revisions. Though "the last time [Nelson Lord] spoke to [Denver] his words blocked up her ears," when he speaks to her again, telling her to "take care of herself," "she heard it as though it were what language was made for" $(B, 252)$. Sethe's attempt to kill Edward Bodwin, when she imagines he is coming for her child, reiterates the central act of violence, her murder of her child, only this time she turns her rage against the white man instead of her own ( $B$, 262). Similarly, when Denver tells Paul D that Miss Bodwin is teaching her things, “ 'experimenting on me' . . he didn't say, 'Watch out. Watch out. Nothing in the world more dangerous than a white schoolteacher" "- though there were few things worse in their pasts than a white schoolteacher "experimenting" on them, 
Paul D does not perpetuate that pain, but instead turns his attention to the future and asks "Your mother all right?" $(B, 266)$.

As a matter of fact, Sethe is not "all right"; she is so low that she has "no plans. No plans at all" $(B, 272)$. But she is not so low that she is incapable of responding to Paul D's special quality, a quality of evoking "feeling" and the desire to "tell" which Morrison terms "blessedness"- "The thing in him, the blessedness that has made him the kind of man who can walk in a house and make the women cry. Because with him, in his presence, they could. Cry and tell him things they only told each other" $(B, 272)$. Again, it is memory that enables Paul D to sort out his feelings: "Suddenly he remembers Sixo trying to describe what he felt about the Thirty-Mile Woman. She is a friend of my mind. She gather me, man. The pieces I am, she gather them and give them back to me in all the right order"; and he realizes that "he wants to put his story next to [Sethe's]." He tells her, "me and you, we got more yesterday than anybody. We need some kind of tomorrow." Their relationship is described in terms of the restoration of Sethe to herself ("You your best thing, Sethe" $[B, 272-73])$ and of the right working of time-of time that "stays put" and allows "plans."

Yet "this is not a story to pass on" $(B, 275)$, and the ambiguity of this refrain-which is repeated three times-tantalizes. Its meaning depends on the meaning of "pass on": does it mean "to communicate" or "to die"? Does the line mean that this is not a story to let live-that is, that it is a story to forget; or that it is not a story to let die-that is, that it is a story to remember and tell? The ambiguity suggests a difficult balance in relation to the past: the past must be remembered, but not entirely; it must be forgotten, but not entirely; it can kill though it can also heal, and it is most healing when remembered in response to another and when "told." Sethe remembers in response to Beloved's need and her story becomes bearable because it is Paul D's as well; she envisions a future in which they find "word-shapes" with which to communicate, as he imagines putting his story next to hers. Morrison has chosen to tell this tale-to pass it on rather than let it pass on-in response to our need, and in a way that emphasizes the remembering and telling as means of reconstruction.

The receptive reader or listener is part of the community restored by the telling, and the story is the means of the restoration. In a remarkable passage, Morrison describes remembering and telling in terms of loving, feeding, nurturing, creating. Denver is mining the past in order to feed Beloved's "craving to know": "Denver was seeing it now and feeling it-through Beloved. Feeling how it must have felt to her mother. Seeing how it must 
have looked. And the more fine points she made, the more detail she provided, the more Beloved liked it. So she anticipated the questions by giving blood to the scraps her mother and grandmother had told her-and a heartbeat. The monologue became, in fact, a duet as they lay down together, Denver's nursing Beloved's interest like a lover whose pleasure was to overfeed the loved Denver spoke, Beloved listened, and the two did the best they could to create what really happened, how it really was" $(B, 78)$. Remembering and telling are generative and restorative acts that endow the past with flesh, blood, and a heartbeat. By "going inside," then reaching outside and telling-by memory and narration-the characters rebuild their world.

Morrison has spoken of Beloved as a writerly text and of her fiction generally as demanding participatory reading..$^{75}$ Beloved enlists the reader's imagination by disrupting chronology and point of view. Past and present are interwoven and time varies according to point of view; point of view is-like time-fluid, shifting from first to third persons, and from one first person to another, in a way that suggests that all are involved with all, that the story is everybody's. This quality may be seen as expressing the connectedness, affiliation, and boundary confusions associated with female identity, but Morrison relates voice in her novels specifically to oral tradition in the black community: "No author tells these stories. They are just told-meanderingly — as though they are going in several different directions at the same time. . . . I am simply trying to recreate something out of an old art form in my books-that something that defines what makes a book 'black.' "776 Events move generally backward, as in an archaeological dig that unearths deeper and deeper layers, moving back to the originating events, the escape and the infanticide. The ending is open and ambiguous-in fact, it was not actually intended as an ending; Morrison says that she intended it as a transition to another part of the book, when the editors declared the book finished. ${ }^{77}$

${ }^{75}$ Personal communication, Claremont, Calif., October 1987. See also Evans (n. 3 above), 341: "Because it is the affective and participatory relationship between the artist or the speaker and the audience that is of primary importance. . . . To make the story appear oral, meandering, effortless, spoken-to have the reader feel the narrator without identifying that narrator, or hearing him or her knock about, and to have the reader work with the author in the construction of the book-is what's important. What is left out is as important as what is there."

${ }^{76}$ Nellie McKay, "An Interview with Toni Morrison," Contemporary Literature 24, no. 4 (1983): 413-29, esp. 420.

${ }^{77}$ Personal communication, Claremont, Calif., October 1987. Morrison says "there is always something more interesting at stake than a clear resolution in a novel” (McKay, 420). 
Throughout the novel the characters have been made to realize that power lay "in the naming done by a whiteman" $(B, 125)$, that "they were only Sweet Home men at Sweet Home. One step off that ground and they were trespassers among the human race ... gelded workhorses whose neigh and whinny could not be translated into a language responsible humans spoke" (B, 125). Morrison's plural and multivocal text wrests the word from the white man and gives it not to the individual author Toni Morrison but to the black community as a whole. Morrison's writerly text is thus also a political text, a work that empowers the disenfranchised and gives speech to the silenced.

$* * *$

Some of the characteristics I attribute to feminist metafiction are qualities that have been associated with "women's writing" and female boundary fluidity-open-endedness, refusal of linearity, processiveness, inclusiveness. ${ }^{78}$ However, I am less concerned with "women's writing" than with feminist fiction, and more specifically, with feminist metafiction, a highly self-conscious, selfreflexive mode that I associate with female identity only when the writer herself does-as Drabble and Lessing do. My description of feminist form has affinities with Rachel Blau DuPlessis's and Joanne Frye's, ${ }^{79}$ though it more resembles descriptions offered by

${ }^{78}$ Christine Makward refers to the "key words" that appear in discussions of women's writing as “open, nonlinear, unfinished, fluid, exploded, fragmented, polysemic, attempting to 'speak the body," " in her "To Be or Not to Be . . a Feminist Speaker," in The Future of Difference, ed. Hester Eisenstein and Alice Jardine (New Brunswick, N.J.: Rutgers University Press, 1985), 95-105, esp. 96. See also Rachel Blau DuPlessis and Members of Workshop 9, "For the Etruscans: Sexual Difference and Artistic Production-the Debate over a Female Aesthetic," in Eisenstein and Jardine, eds., 128-56; and Josephine Donovan's description of a women's aesthetic rooted in "a woman-centered epistemology" in her article, "Toward a Women's Poetics," Tulsa Studies in Women's Literature 3, nos. 1/2 (Spring/Fall 1984): 99-110. Judith Kegan Gardiner suggests that "the processual nature of female identity illuminates diverse traits of writing by women": "female identity is a process" and "writing by women engages us in this process" ("Female Identity and Writing by Women” [n. 68 above], 349, 361).

${ }^{79}$ DuPlessis analyzes twentieth-century women's fiction as "writing beyond the ending," beyond the telos of romance and its "regimen of resolutions" (Writing beyond the Ending: Narrative Strategies of Twentieth-Century Women Writers [Bloomington: Indiana University Press, 1985], 21). Joanne S. Frye attributes to first-person narrative powers of subversion like those I attribute to metafiction, arguing that first-person narrative allows the protagonist "agency" and "engages the narrative process in rejecting fixed plot or teleological structure" (Living Stories, Telling Lives: Women and the Novel in Contemporary Experience [Ann Arbor: 
Mary Jacobus, Margaret Homans, and Annette Kuhn, who attribute radical potential to self-conscious modes. ${ }^{80}$ Feminist metafiction has affinities with the "polyphonic novel," which Julia Kristeva describes as engaging in a " 'transgression' of linguistic, logical, and social codes," and with Hélène Cixous's "l'écriture féminine," "new insurgent writing" that subverts hierarchies and "wreck[s] partitions, classes, rhetorics, regulations and codes," thereby "chang[ing] the rules of the old game." ${ }^{11}$

Unfortunately, feminist fiction of the sort I have described has passed with the seventies, as white women's fiction has participated in postfeminist retrenchments of the eighties. Lessing, Drabble, and Atwood continue to be concerned with many of these same issues, but they no longer envision the possibility of change. In Drabble's 1987 The Radiant Way, Elizabeth concludes her search for the past with the questions, "What did it matter who her father was? . . . What does it matter who I am?"; and Alix, who has been politically committed all her life, withdraws from political action. ${ }^{82}$ Atwood's Cat's Eye (1988) is a feminist quest gone awry, a search

University of Michigan Press, 1986], 71, 9). Frye refers to women's plots as "based on process rather than product" $(40-41)$ and notes their writerly qualities: "the female experiences characterized in the novels extend beyond the novels' boundaries to the extraliterary world of the reader. These novels, therefore, call upon. . the involvement that Roland Barthes calls 'writerly' " (201).

${ }^{80}$ Jacobus, "The Difference of View" (n. 9 above). Margaret Homans grounds some of Jacobus's generalizations in specific analyses of Anglo-American women writers, describing women writers as "simultaneously appropriating and rejecting the dominant discourse” (Margaret Homans, “ 'Her Very Own Howl': The Ambiguities of Representation in Recent Women's Fiction," Signs 9, no. 2 [Winter 1983]: 186-205, esp. 205). Annette Kuhn, Women's Pictures: Feminism and Cinema (London: Routledge \& Kegan Paul, 1982), distinguishes between two types of "cultural practice, one which tends to take processes of signification for granted and one which argues that the meaning production is itself the site of struggle" (17): "meaning production" is not "taken for granted, exactly because the ideological character of the signification process is regarded as itself something to be challenged" (18). She defines a "radical signifying practice" as "a mode of representation which . . . makes the moment of reading one in which meanings are set in play rather than consolidated or fixed" (12).

${ }^{81}$ Julia Kristeva, "Word, Dialogue, and Novel," in Desire in Language: A Semiotic Approach to Literature and Art, ed. Leon S. Roudiez (New York: Columbia University Press, 1980), 64-91, esp. 71, 86. Hélène Cixous, “The Laugh of the Medusa," trans. Keith Cohen and Paula Cohen, Signs 1, no. 4 (Summer 1976): 875-93, reprinted in New French Feminisms: An Anthology, ed. Elaine Marks and Isabelle de Courtivron (Amherst: University of Massachusetts Press, 1980), 245-64, esp. 250, 256. Again, Cixous's and Kristeva's generalizations make no reference to specific writers.

${ }^{82}$ Margaret Drabble, The Radiant Way (London: Weidenfeld \& Nicolson, 1987), 385. 
for the past yielding little illumination and ending in repetition of the word "nothing"; and the novel's self-conscious "postfeminism" is underscored by repetition of the word. ${ }^{83}$ Lessing tends to sentimentality concerning women in the Jane Somers novels and to a chilling cynicism in The Good Terrorist (1985) and The Fifth Child (1988), but nowhere in her recent fiction do we find the political edge of The Golden Notebook. ${ }^{84}$ In this climate Beloved stands out the more strikingly for its collective and liberatory vision, for a delving of the past that allows a transformed future.

Department of English

Scripps College

${ }^{83}$ Margaret Atwood, Cat's Eye (New York: Doubleday, 1989), 90, 238, 242.

${ }^{3}$ As I argue in "The Diaries of Jane Somers: Doris Lessing, Feminism, and the Mother," to be published in Narrating Mothers, ed. Brenda O. Daly and Maureen Reddy (Knoxville: University of Tennessee Press, 1991), in press. 